\title{
Dancing after Philosophy
}

\section{Adam Rosen-Carole}

Sholtz, Janae, The Invention of a People: Heidegger and Deleuze on Art and the Political (Edinburgh, UK: Edinburgh University Press, 2015), 298pp.

$\mathrm{I}$

n "Why Still Philosophy" Adorno exhorts, "Philosophy should not with foolish arrogance set about collecting information and then take a 1 position; rather it must unrestrictedly, without recourse to some mental refuge, experience: it must do exactly what is avoided by those who refuse to forsake the maxim that every philosophy must finally produce something positive. Rimbaud's 'il faut être absolument moderne' is neither an aesthetic program nor a program for aesthetes: it is a categorical imperative of philosophy."1 In The Invention of a People: Heidegger and Deleuze on Art and the Political ${ }^{2}$ Janae Sholtz embodies, by patiently pacing out, indeed in a way dancing, the contemporary meaning of Adorno's injunction. Giving herself over to while at once reflexively working through her paradoxical inspiration by both Heidegger and Deleuze, Sholtz performs, in the most unguarded yet formally self-conscious manner, and in a way entirely unprecedented in the literature, the unreservedness of philosophical experience. And thereby she enacts, in the most exemplary manner, the possibility of self-possession amidst the wild enthusiasms and despair of the contemporary. In the face of the most bewitching solicitations of twentieth century philosophy (Heidegger and Deleuze) and the nearly overwhelming temptation to resigned thoughtlessness or self-indulgent scholarship (whether this be "creative" or rigoristic) issuing from the unavoidable experience of the generalized and emphatic social inconsequence of philosophy, Sholtz performs the integrity of thought. Refusing every mental refuge, including scholarly supplication to a projected master, self-willed iconoclasm, easy amelioration, and fantasmatic position-taking, Sholtz's authorship embodies, gracefully, an autonomy that is no insularity, let alone feigned self-sufficiency, but on the

${ }^{1}$ Theodor Adorno, Critical Models: Interventions and Catchwords, trans. by Henry W. Pickford (New York: Columbia University Press, 1998), 17.

${ }^{2}$ Janae Sholtz, The Invention of a People: Heidegger and Deleuze on Art and the Political (Edinburgh: Edinburgh University Press, 2015).

(c) 2017 Adam Rosen-Carole

https://www.kritike.org/journal/issue 21/rosen-carole december2017.pdf

ISSN 1908-7330

(cc) BY-NC-ND 
contrary, the accomplishment of bearing the passion, the urgency, and the limits of thought, palpably, within thought. Such autonomy is an elegant discomposure (dance begins and, with each significant development, begins anew with a stumble, a risk of utter collapse or recovery though the merely habitual). Autonomous ("unrestricted") experience is materially actualized-embodied-in her authorship not as formal self-legislation or imaginative idiosyncrasy, but as independence of thought; in part, but only in part, as resistance to, by way of gliding past, hegemonic choreographies of philosophical practice, or at once more accurately and more generally, as graceful refusal to fall into step with what is. Such autonomous experience is in every way untimely. Ironically, the ecstasy of inspiration by Heidegger and Deleuze becomes the condition for a philosophical and writerly autonomy far more moving in its reservedness than are the erotic exhilarations, both scholarly and poetic, ordinarily encountered in writing on these two modern muses. In this truly extraordinary work, which, as we will come to see, is very much a work of mourning, autonomous experience-which is to say, philosophical experience-becomes possible for one long done with philosophy; one who dances, seriously, through philosophy's aftermath or afterlife.

While overcoming, in the sense of achieving independence from, her primary sources of inspiration is in large part what is at stake in the construction of Sholtz's authorship, to be sure The Invention of a People is and must be engaged in reconstructing and comparatively evaluating the mutual mediations of ontology, philosophy of art, and ethics/politics in the work of two thinkers who Sholtz takes to be the most compelling and fully realized contemporary voices addressing the question of what it would be to overcome metaphysics as transcendence and totalization: Heidegger and Deleuze. In short, her thesis is that both Heidegger and Deleuze develop their post-Nietzschian, anti-Platonic ontologies through their philosophies of art, which in turn model and according to which artworks provide the experiences requisite for their respective ethics/politics such that overcoming (Platonic) metaphysics becomes, for both, an endeavor of sustaining responsivity to the openings afforded by aesthetic experience. In this regard, Sholtz embarks on the recognizable philosophical task of comparing the parallel trajectories of two thinkers concerned with overcoming metaphysics in view of the differences of philosophical sensibility driving them to diverse, indeed partially incompatible, conclusions. And while it is clear that Sholtz favors Deleuze's orientation to unprescriptable and unforeseeable dispersive differentiation (the rhizomatic) and his affirmation of endless errancy, wandering, and aleatory innovation (the power of the false) over Heidegger's orientation to gathering, especially gathering in and as logos or as the truth of a people's historical-cultural endowment, as well as his fixation of difference

(C) 2017 Adam Rosen-Carole

https://www.kritike.org/journal/issue 21/rosen-carole december2017.pdf

ISSN 1908-7330

(cc) BY-NC-ND 
as ontological difference-Deleuze is frequently presented as "radicalizing" Heidegger-it is by no means incidental that, while her preferences are altogether evident, they are by no means prescribed. Interesting in this connection is that Sholtz's treatments of Heidegger are far more extensive and fully developed than are her treatments of Deleuze, who she evidently favors; to this we will return. For now, allow me to note that without the slightest impulse to proselytize and establish a new Deleuzian orthodoxy (which impulse is rampant in the Deleuzian literature, as was the case in the Lacanian literature of the recent past), her impassioned preferences become altogether evident; yet because these preferences remain visibly such, that is, passionate preferences rather than polemicized programs, they remain exposed to subtle yet consistent undercurrents of challenge throughout the text which, as we will see, bear Sholtz's thought beyond the limits of the contemporary literature on Deleuze, and perhaps beyond her explicit intentions, while bringing it into touch with the most pressing questions concerning philosophical practice in the political present. Ultimately, I will claim that the comparative brevity and underdeveloped character of Sholtz's treatments of Deleuze are crucial indications that her Deleuzian preferences are by no means dogmatic but, quite the contrary, are being tested, challenged, and partially divested in order that her thought remain unreservedly available to experience, certain crucial features of which would be blocked by Deleuzian enthusiasm. Against the backdrop of her magisterial expositions of Heidegger, the comparatively cursory and coarse and, in this precise sense, explosively impassioned expositions of Deleuzian thematics become visible as something like a last grasp at the untenable, a disappointed idealism, or as a necessary liberty afforded by a part of her authorial persona to another part that has not yet overcome its inaugural passion and thereby impedes a higher coherence, i.e., inhibits the authorship from coming more fully into its own.

Before this can be unpacked, two remarkable features of Sholtz's nonprescriptive yet passionate discourse must be underlined, as they clarify the significance of her authorship; and as should be clear by now, I take it that the construction of her authorship, far more than her reconstructive and comparative philosophical labors per se, as impressive as they are, is what makes the text so remarkable, indeed invaluable. That is, while her expositions of Heidegger and Deleuze are superb, ${ }^{3}$ they cover familiar territory, and her claim that Deleuze "radicalizes" Heidegger often seems a slight of hand given that, as Sholtz notes repeatedly, Heidegger and Deleuze are often asking far different questions despite their shared orientation to overcoming metaphysical transcendence; for Deleuze to "progress" with

\footnotetext{
${ }^{3}$ Let there be no misunderstanding: even though Sholtz's treatments of Heidegger are far superior to her treatments of Deleuze, the latter are still highly impressive.

(C) 2017 Adam Rosen-Carole

https://www.kritike.org/journal/issue 21/rosen-carole december2017.pdf

ISSN 1908-7330
}

(c) $)$ BY-NC-ND 
respect to Heidegger, their interests and problematics would have to converge far more than they do. The construction of her authorship, however, is entirely unprecedented and deserving of the utmost thoughtful attention.

First, the palpable absence of universalizing impulses comes off not as self-restraint but feels more like serene self-sufficiency, a neo-aristocratic comfort in one's own skin. While neither confrontational nor piercing in the manner of Marina Abramović, Sholtz's authorship embodies a steady composure and integrity, or more like a resolute, full-blooded being at ease with oneself, an autonomous presence, and an absolute seriousness and attentiveness that resonates with Abramovićs feminist performative practice and should be considered in its wake. ${ }^{4}$ Not only her manifest preference for Deleuze over Heidegger but her authorship generally exhibits, strikingly, an almost effortless reserve there where others would hardly be able to hold themselves back. Consider the following passage: "we refrain from any critical evaluation of [Heidegger and Deleuze's] respective interpretations of Nietzsche, [to which the first Part of the book is devoted!] but rather treat this moment as a productive space of convergence from which to draw insights as to why the two thinkers are committed to certain ontological positions and to explain how their philosophies concerning the function of artworks differ." 5 Most emphatically in her discussions of Deleuze, but also nearly any line from her discussions of Heidegger could be put forward as evidence of this, Sholtz demonstrates an astonishing reserve: she says just enough to clarify the position without overindulging, ${ }^{6}$ which so often means projecting an argumentative infrastructure or underscoring an immediate political pertinence which is both questionable in itself and betrays anxieties amplified through the very means by which they would be assuaged. Inspired yet utterly self-possessed, Sholtz's writing remains patient and discerning while

\footnotetext{
${ }^{4}$ Like Abramović, Sholtz's performance achieves a formidable self-presence, enacting an uncompromising self-possession that becomes the condition for extreme self-expansion, going beyond the limit, testing "what a body can do." While the differences between Abramović and Sholtz are altogether obvious-for instance the line that leads from Abramović to Cindy Sherman has no bearing on Sholtz's performative practice, Abramović's penchant for histrionics and her interest in purification and perhaps transcendence have no echo in Sholtz, and Sholtz displays nothing of Abramović's courting of disaster for the sake of exposing, confrontationally, the social unconscious, or the extent of manifest misogyny-for both, the embodied self is very much on the line and, in large part, their accomplishment is the persistence of the embodied self under conditions hardly conducive to it. It may be, as well, that for both it could be said that the plural body is the house of being.

${ }^{5}$ Sholtz, The Invention of a People, 14.

6 'Standing still is not actually 'still.' Balancing on two legs demonstrates to the dancer's body that one moves with gravity, always. Observing the constant adjustments the body makes to keep from falling calms the whole being. It is a meditation. It is watching the reflexes at work, knowing they are subtle and dependable - not just emergency measures." Steve Paxton, "Fall After Newton," in Dance, ed. by André Lepecki (London: The MIT Press, 2012), 63.
} 
never becoming rigoristic, thus authoritarian or aggressively self-assertive: there is no stampeding toward conclusions, officious reprobation of alternative readings, or marshaling of mountains of evidence in favor of an interpretation none the more convincing or secure for it.7 Sholtz's writing paces out positions rather than arguing or polemicizing. Though her expositions are forceful, radiating a contained passionate intensity, she remarkably manages to suspend language as command. Her elevated but never rapturous rhetoric dignifies both topic and authorship without overclaiming.

Let this be clear: this is the book we did not know we were waiting for; a book on Heidegger and Deleuze that, finally, manages to refrain from arguing, convincing, and interpretively innovating (and so manages to divest the power-imbued fantasies of philosophical community elaborated thereby), that puts to rest all meditative stalking and enthusing, that feels no need for exegetical finesse or power brokering, and simply is-which is no small thing, but a tremendous accomplishment of powerlessness (Gelassenheit). This is a book-a writerly, dancerly event-that dispenses being, not advice, let alone existential guidance or political prescription, or scholarly insight: it is as it performs, an extraordinary susceptibility to being, which is to say, undiminished experience. Serenely uninterested in willful dominance, selfinsistence, dramatic self-destitution, or attunement to concealedness, everything in Sholtz's authorship is on the surface, maintained, invitingly, in its reservedness (Verhaltenheit). In this respect, the text is a performance-event of her notion of a people-to-come.

Exemplarily, Sholtz's authorship is uninterested in power, whether this be the power of reason, of conversion-inclined polemics, or of spectacle, but rather in finding its pace and space, in clarifying impressions and testing their coherence, in allowing what comes of minor doses of inspiration when thought is dedicated to their undergoing, and thereby, in finding the essential movements of her écriture. Unlike the pursuits of écriture féminine in which the sonorous materiality, embodied, affective, and drive-based relationality, and psychic reservoirs of language subtending its hegemonic semantic surface are developed as sites of resistance and speaking and being otherwise, Sholtz's écriture, while as keyed to the ethical-political latencies of the unthought as are these more familiar practices, does not give itself over to the

${ }^{7}$ In relation to this, Sholtz also cites Heidegger's hyperbolic admonishment that " the officious will to refute never even approaches a thinker's path' (NIII/IV, 229)." Cf. Sholtz, The Invention of a People, 40. While I will be unable to dedicate extended attention to this, and only comment on it periodically, note that Sholtz's text progressively explicates its performative principles, leaving a trail of breadcrumbs for those who would enter into its self-consciousness. The implicit progressive (but nonteleological) self-consciousness of the performance manifests both at the level of thematic development and through such textual moments as the above. See, for example, Sholtz, The Invention of a People, 53, 57, 78-9, 85, 108, 151, 268.

(c) 2017 Adam Rosen-Carole

https://www.kritike.org/journal/issue 21/rosen-carole december2017.pdf

ISSN 1908-7330

(cc) BY-NC-ND 
discomposure of embodying the excavated repressed, 8 e.g., performing the tension of the semiotic and the symbolic or pursuing an erratic and erotic practice of writing as a critical rejoinder to the façade of rational neutrality sustaining and sustained by such repression. For it does not presume to offer itself as a model or mimetic training ground for a progressive ethical/political future; nor does it presume that resistance to the repressive symbolic order can but take shape as its eternal ironizing or intermittent disruption. ${ }^{9}$ In the wake of Deleuze, Sholtz gives credence to the power of the false, to a sense of the world as teeming with transformative, truly novel, interstitial possibilities. (Her caution in this regard will be discussed later.) Implicitly in dialogue with the likes of Cixous, Clément, Irigaray, and Kristeva, but significantly differing from them in ways necessary to bring the practice of écriture féminine into contact with and continue it in the context of a greatly transformed affective, political, and intellectual culture, Sholtz's eminently composed discourse presumes "merely" to go its own way, to work its way through and out of its compelling sources of inspiration, that is, to "overcome" its impassioning investments, which in no way means simply leaving them behind but rather achieving the thoughtful integrity of unreserved experience that cannot be had, simply, with or without them. Her negotiations of her passions, and the way this facilitates undiminished experience, are enactments of her dancerly autonomy: each movement of her writing attains its full significance through a structuring choreography, yet feels, within itself, free. And it is precisely in virtue of its eminently selfconfident composure that her writerly, dancerly performance issues an invitation to follow suit in one's own way: freedom beckons to freedom. ${ }^{10}$ But it is also through its remarkable reserve that her authorship acknowledges the social and political powerlessness of philosophical practice without indulging in despair or disavowal. One can always decline to dance. Very much unlike the style of performance art that makes audiences anxious by explicit gestures of recruitment, and equally far from Brechtian endeavors of audience politicization (proletarianization), Sholtz's performance, through its

8 Which is perhaps hyperbolically intensified and disarrayed on account of its repression, and perhaps further on account of its need to resist immediate occlusion or facile incorporation.

${ }^{9}$ In this way, Sholtz's authorship—-the persona or mask that affords a freedom to exceed her conscious intentions, to pursue that which her self-conception, e.g., as a Deleuzian, will not allow-takes a distance from the Deleuzian minoritarian strategies that the text explicitly, if somewhat tentatively, champions. Consider also the distance Sholtz's authorship takes, in its performance of self-possession, from the Deleuzian inclination toward the chaotic-cosmic, his "lean[ing] toward the thought of the infinite" and "maintain[ing] just enough consistency to become imperceptible." Sholtz, The Invention of a People, 68. Numerous further examples of such a performative displacement of Deleuze could be adduced.

${ }^{10}$ Sholtz, The Invention of a People, 53.

(C) 2017 Adam Rosen-Carole

https://www.kritike.org/journal/issue 21/rosen-carole december2017.pdf

ISSN 1908-7330

(cc) BY-NC-ND 
enthralling self-composure, simply and subtly extends an open invitation. ${ }^{11}$ Ironically, though her claim is that for Heidegger as for Deleuze, through the experience of art, a people-a being-together-in-difference-is inaugurated or at least afforded an essential condition of possibility, her artistry - and it is indeed artistry - is far less sanguine about, or even as manifestly concerned with, its social uptake, its ontological-political "work," than are Heidegger and Deleuze; yet it is through this emphatic self-composure that such work becomes possible. Not just in this respect but most generally, the Heideggerian and Deleuzian thematics deftly expounded by Sholtz are challenged, complicated, and indeed frequently contradicted by her authorial performance.12 The enabling condition-and consequence-of this challenging and dynamic reworking is Sholtz's resolute, attentive exposedness to the social-political present: a conjuncture in which ontology, art, and politics are as unlikely to save us as a god, and in which interstitial

11 Though caution here would certainly be necessary, Sholtz's practice might be usefully considered in light of Michael Fried's art-historical notion of "absorption." Cf. Michael Fried, Absorption and Theatricality: Painting and Beholder in the Age of Diderot (Berkeley, University of California Press, 1980); Art and Objecthood: Essays and Reviews (Chicago: University of Chicago Press, 1998); Why Photography Matters as Art as Never Before (New Haven: Yale University Press, 2008). Of particular interest in this connection is Sholtz's refusal, or better, evident disinterest in enigma, its displacement by reservedness and how this bears on her reconfiguration of the antitheatrical imperative, of facingness, and of the accomplishment of presence.

The invitation extended by Sholtz's performance, or more precisely, the manner of this invitation's extension, suggests a limited analogy with psychoanalytic practice. Notice that an open invitation is extended there where, given the ethical/political concerns of the text, one might expect interpellation, i.e., rhetorically amplified gestures of recruitment. What Sholtz offers is not a path, a new orthopraxy or orthodoxy, but permission, namely, permission of the kind an analyst can offer: permission to pursue what inceptively but due to resistances issuing from obscure, rationalized authority, distortedly, one was pursuing already. Her work, as Heidegger says of the work of art, is the letting arrive (dawn) of what is emerging into presence. Further connections with psychoanalytic practice will be considered below.

Bearing in mind both Sholtz's anti-theatrical accomplishment of presence (the connection with Fried) and the way she extends an open invitation through enthralling composure or "absorption" (the connection with Freud), consider that her performance is and must be a matter of self-showing, phainesthai, (now a connection with Heidegger) that never becomes theatrical, extravagant; that it is and must be luminous but never dazzling; and this is how it avoids obscurantist, thus repressive, enchantment, i.e., the production of manipulability (now a connection with Spinoza and Adorno). That these disparate regions of thought would so elegantly come together is nothing less than bewildering. It is also, incidentally, a terrific example of the type of unforeseeable convergence that motivates, and perhaps validates, the specific forms of extra-conceptual comprehension pursued by the Deleuzian "idea."

${ }^{12}$ Sholtz, as authorial persona, is anything but Heidegger's poet or Deleuze's nomadic, anomalous pack animal becoming minoritarian and ultimately imperceptible. Her performative practice evinces neither the despair nor the optimism of Deleuze's interstitial micropolitics. There is neither erratic or chaotic multiplicity of forces evident in her performance nor evidence of unregulated becomings; on the contrary, everything is measured, calibrated, confident. And very much unlike the destinal, homeland-bound address of Heidegger's poet, Sholtz' authorship manifestly knows not to whom it speaks: she dances, if not simply for herself, then in the dark.

(c) 2017 Adam Rosen-Carole

https://www.kritike.org/journal/issue 21/rosen-carole december2017.pdf

ISSN 1908-7330

(c) $\mathrm{BY}-\mathrm{NC}-\mathrm{ND}$ 
possibilities facilitate the reproduction of control societies, yet in which refusing to be bullied into despair and to succumb to the enormous pressures of stupification (a-musement) is still a meaningful option. One can yet dance, with spritely seriousness. ${ }^{13}$

That Sholtz's impassioned authorship remains as composed as it does, unavoidably interested in its social uptake without devolving into overeagerness, is all the more remarkable given the company she keeps. The Invention of a People may be the first extended treatment of Deleuze that goes in for neither clamorous anarchic naiveté nor sophistical metaphysical extravagance; ${ }^{14}$ the first extended treatment of Heidegger that avoids reactionary impulses altogether. Her writing is utterly balanced, measured, graceful: there is no stern Heideggerian condescension and none of the imperative impetuousness or ruthless affirmative demands of Deleuzians. Never acceding to rapturous heights or enigmatic meditative depths, it seeks to be artful and thereby to inspire a people to come, but knows that under foreseeable conditions of reception it is bound to be but "aesthetic:" contemplatively enjoyed rather than existentially-politically inceptive. That within itself it resists but does not refuse or deny this fate is a measure of its attunement to the present, its capacity for experience. The text knows itself to be, and conducts itself as, addressed primarily to an audience of philosophers, ${ }^{15}$ thus refrains from any audacious, conscience-assuaging,

${ }^{13}$ Pichet Klunchun's account of his dance practice seems, in many respects, an apposite characterization of Sholtz's: "As a demon dancer, I know this risk and this fight well. As a demon I will always lose and upset the world-yet I keep dancing. Why? Because I also know that my dance is grounded in a tradition of discipline, patience, precision, and intense concentration, and that my dance, including its future, is open, and that I fight against what I and the world have become. So, I will continue to dance until I have changed, until the demon wins, until the demon comes out ahead, until the world transforms, dancing with great patience, precision and focus. That is what I am daring to do. That is why I have danced. That is my future perfect dance." See Pichet Klunchun, "Thoughts on the Future Perfect of My Dance as Demon," in Dance, 31.

${ }^{14}$ Indeed, Sholtz downplays Deleuze's metaphysical self-indulgence as much as possible, just to the near limit of distortion.

${ }^{15}$ The extended treatments of Heidegger interwoven with discussions of Deleuze, who has lately received eager, arguably overeager, attention within diverse fields of practice, ensure that the text remains primarily addressed to philosophers. The altogether evident waning of the Heideggerian star, thanks to the persistent, pervasive prejudice against his work and the negative attention occasioned by the recent publication of the Black Notebooks, makes the present moment one in which extended discussion of Heidegger is likely to repel most readers without a formation and professional interests in philosophy, not to mention even many professional philosophers. Thus, it should be noted that while the extensive treatments of Heidegger are likely to repulse fervent Deleuzians and so prohibit the diverse uptake which writings on Deleuze tend to enjoy, the concern with Deleuze is likely to repulse philosophers as much as, if not more than, the concern with Heidegger; and in this way, that is, by depriving itself of any readymade audience, Sholtz's text performatively embodies the modernist demand to "construct" its own audience, which would be, in her idiom, to "invent a people." But the difference here, which is to say, the displacement, while slight, is crucial. The modernist demand that artworks 
fantasmatic calls for revolution, and thereby takes the measure of its historical moment and dares to install itself resolutely within that moment rather than project past it. Philosophers are no longer, if they ever were, a vanguard. Exceptionally clear structures of thought become a platform for, rather than an excuse for neglecting, rhetoric, i.e., appearances, and in this

autonomously elaborate the proper conditions for their reception-i.e., through themselves cultivate taste for and induce practical responsivity to, which in part, paradoxically, means innovating in light of, their novel and singular accomplishments-was itself a recognized criterion for high artistic achievement whose satisfaction could signal, at once, independence, strength, and belonging. To satisfy this demand was for a work, which initially could not but strike as "ugly" or otherwise obnoxious, to construct for itself a community of taste and to inspire successors, thus to stake out its place within modernism as legacy or tradition, however paradoxically such in virtue of its being a tradition continued and renewed through freedom. In short, even if its significance, stakes, and reverberations exceeded the restricted domain of the artworld, the modernist demand was addressed to and through known institutional channels. Sholtz's aspirational invention of a people is addressed to no one. Or rather, to no one in particular, no privileged or proper audience. Not even, really, to a surrogate audience, as the artworld, following a Schillerian idea, was once thought to be a plenipotentiary or placeholder for an absent politics. The performative practice by which a people would be invented is not addressed to and through the artworld or any analog, e.g., the "world" of contemporary philosophy; it has no appropriate institutional medium, no welcoming field of reception. It would be accomplished one knows not how; and in this not knowing, specifically in not knowing how a people so invented would be more than a fleeting frame of mind or an immediately dissipating feeling of urgency and common purpose, is the critical insight that the contemporary social fragmentation into a proliferating plurality of practices does not amount to the invention of a people, though the invention of a people could not be anything other than this, just otherwise. Only because the text remains unruffled by all its unknowingness can it clearly convey, that is, convey as clearly as present reality allows, that the difference between the present disaster and a people to come is that slight adjustment of which Benjamin, and in his own way Adorno, spoke of in connection with the idea of the messianic. In other words, the success criteria for the invention of a people can be provided only by the world, not independently by thoughtand the world has not offered much in this regard. Hence the necessity of Sholtz's performative poise. Her reserve is a waiting, a waiting to witness, i.e., an availability to experience. [This aspect of Sholtz's work connects with the best elements of Deleuze's analysis of the crystalline regime in Cinema 2. See Gilles Deleuze, Cinema 2: The Time-Image, trans. by Hugh Tomlinson and Robert Galeta (Minneapolis: University of Minnesota Press, 1989). It is, in other words, a withstanding of temptations to despair (withdraw) and to optimistically exaggerate (act out): a courageous, exemplary accomplishment of remaining present to experience and to oneself. Only when and insofar as it becomes evident that Sholtz dances, almost ineluctably, by and for herself, thus that her performative autonomy is, however compelling and thereby inviting, conditioned by and an elaboration of the socially enforced unknowingness of what movements would inspire the invention of a people, i.e., takes shape as a reflexive engagement and a thereby refusal of reconciliation with its socially enforced solitude, is the question of the invention of the people properly posed in its historical-political (material) rather than intrinsic opacity. The invention of a people cannot be merely a matter of reconfiguring communities of taste ("an aesthetic program"), but nor can it be a direct political initiative, whether institutionally mediated or resolutely localistic. Tenaciously holding onto this unknowingness, thus capable of appreciatively attending all manners of practical-creative assemblage while at once refusing to ignore their limits, is how the problematic of the invention of a people is maintained on the narrow path between Scylla of enthusiasm and the Charybdis of despair.

(C) 2017 Adam Rosen-Carole

https://www.kritike.org/journal/issue 21/rosen-carole december2017.pdf

ISSN 1908-7330

(c) BY-NC-ND 
way the text attests to its awareness that the conditions for its success at invoking a people to come are extrarational, "all too human." But also in this way, that is, through her elevated but never overinflated rhetoric, Sholtz displays her disinterest in merely adding to the voluminous scholarship on Heidegger and Deleuze. On one level she does want to insist, against reigning scholarly sensibilities, that Heidegger and Deleuze can be productively read in conjunction. But her highly crafted rhetoric clearly suggests that much more than an academic contribution is being pursued. Were that her primary goal, the rhetoric would be but ornament. Sholtz's language, rather, is the medium of her spritely serious performance. Against and in view of expository theses intelligently ordered, her language embodies a perpetual upsurge of transient, intense significance that such theses cannot quite contain, a minor eloquence, and therewith an inceptive and provisional performative elaboration of the forms of meaningfulness that would be incumbent to a people to come. Uplifted but never rapturous, an ebullient swirl rather than-and as tacit criticism of-a meandering verbosity or overrefined terseness, Sholtz's language, like her authorship, embodies a measured, balanced, yet passionately stirring utopia of the ordinary. Language, thought, and experience are aligned, for a utopia of the ordinary is precisely the meaning of a people to come.

More than impressive, it is perhaps necessary that Sholtz's authorship engages such extravagant muses in order to attain its sustained composure. What Heidegger and Deleuze afford, namely, experiences of the inordinate, the allure of excess, multiplicity, and opacity, become the condition for Sholtz's graceful phrasing through which thought is steadied, calmed by her enclosing language. Her language is calibrated with laser precision, shaping the object of thought rather than taking flight into a rhetorical autonomy that presumes to be a powerful revolutionary forceand thereby Sholtz clearly indicates her understanding that the conditions for success at invoking a people to cannot be "merely rhetorical." Hence, her language is never scintillating, evocative, or incantatory, though it continually edges toward profane illumination. Not exactly sober, but steadying, her language is utterly without levity, always to the near side of sublimity, yet nothing less than inspired. Graceful phrasing effects minor moments of redemption, modeling, as well as can be done at present, the deflationary utopia of the happiness of thought ${ }^{16}$ - what was earlier termed autonomous experience-implicit in her authorship.

Never demure but reserved, Sholtz's language attains a remarkable precision: most often, to say more would be overreaching, allegorical (i.e., projection, and at the limit, delusion), while to say less would be to invite

16 Theodor Adorno, "Resignation," in Critical Models, 293.

(C) 2017 Adam Rosen-Carole https://www.kritike.org/journal/issue 21/rosen-carole december2017.pdf ISSN 1908-7330 
allegory $\cdot{ }^{17}$ That is, both more and less would conduce to enthusiasm, whereas Sholtz's rhetorical fine-tuning exhibits an exemplary reservedness, a refusal to answer questions that reality alone can answer, and has not yet. ${ }^{18}$ In her language as in her authorship generally, there is no erratic or chaotic multiplicity of forces, no vertiginous peering into murky, abyssal depths, no invocation of archaic or otherwise sublime metaphysical energies. Rather than taking shape as reverie or stultified mystification, experiences of the impossible facilitated by Heidegger and Deleuze become, through Sholtz's patient, precise phrasing, resources for a steadying, withstanding composure.

While her authorship embodies a confident autonomy, Sholtz resolutely refuses to say "I," let alone advocate or embody self-interest. In this way she takes her distance from philosophical and political liberalism. She writes in the first-person plural, saying "we" rather than "I." This is not an imperious "we," arrogant and threatening in its theatricalized claim to be secured against dissent, sovereignly reposed within itself. Nor is a "we" that bespeaks complacent communitarian insularity or overconfident brittleness. It is not a partisan "we," though it does occasionally emit the waft of a manifesto. Most importantly, this is not a "we" that cannot say "I," but rather a performative refusal to appropriate what may, indeed must, be left in common, thus an invitation, or at least an opening. ${ }^{19}$ Sholtz is not primarily concerned with finding her voice, that is, with finding the words with which to express her singular experience of the world or staking a claim within the philosophical territory she traverses, but rather with performing a resonant thinking of a people-to-come. Her authorship is very much a performance, indeed a (partially proleptic) performance of a people-to-come, which, exemplarily, remains fully aware of its powerlessness without hysterically grasping for power or aggressively cultivating the spectacle-power of its powerlessness. Rather, Sholtz lets be a people-to-come. The essential presupposition of her performance is that the main issue-realizing a peopleto-come-cannot be forced; such a people is not an object of political or philosophical construction. "A people is, and must always be, to come. This

${ }^{17}$ Or else signal dismissive condescension.

${ }^{18}$ The immanent infelicities of the text often result from failures to sustain this reserve, to maintain this difficult poise. For instance, when Sholtz writes, clarifying the ek-static rather than authentic/recuperative character of a people-to-come, that "a people does not look inside itself to pull out something hidden that is more meaningful, greater and purposeful, but is created in responding to the outside, a perpetual becoming other-not a historical becoming, but a cosmic becoming which arrives from the future, as the outside, rather than the past," one wonders whether this thought is yet thinkable, whether we have sufficient experience to so much as think a world not essentially imaged as and by the spellbound present. On the other hand, Sholtz may at times overdo the priority of actuality over possibility. This will be considered below.

${ }^{19}$ At times, Sholtz's "we" is an emphatic "I." See Sholtz, The Invention of a People, 5.

(c) 2017 Adam Rosen-Carole

https://www.kritike.org/journal/issue 21/rosen-carole december2017.pdf

ISSN 1908-7330

(c) $)$ BY-NC-ND 
is the impossible possibility that corresponds to thinking as becoming and creation as opposed to will to truth (QP 55/54)." ${ }^{20}$ A people, here, is not an object of calculation but a performing, that is, a thinking: what comes, if it comes. $^{21}$

The second feature of Sholtz's nonprescriptive yet passionate discourse that must be underlined is that, as already indicated, she knows her Deleuzian preferences to be unlivable. While in some ways she struggles with this, resists it, her authorship manifestly stops short of a full throttle embrace of Deleuze, allowing the difficulties and dangers of Deleuze's political ontology to become evident in a way that impedes straightforward advocacy. ${ }^{22}$ In no way does Sholtz give herself over to an unqualified affirmation of the Deleuzian "vision" by which she is clearly inspired, and through her resistance she registers social-political impasses of the present that we cannot merely wish our way past. This is to say, Sholtz's withstanding of her wish to simply be a Deleuzian, her foregoing of immediate enthusiasm for the program she passionately pursues, functions as a psychosocial diagnostic of less tempered treatments of Deleuze. ${ }^{23}$ That her expositions of Deleuzian concepts are energetically exploratory, elaborating a wish for practicable forms of ethical/political resistance and liberated forms of social life while taking their measure against the demands of present reality and attending their internal infelicities, signals that her authorship sides more with wish-analysis than with fantasmatic wish-fulfillment, yet, equally importantly, is strong enough to sustain its wishfulness, knows its value. Her withstanding is no Beckettian waiting, and as such it registers the sociopolitical possibilities of the present that we cannot merely wish our way into. This is one crucial way that Sholtz's authorship models, or better, embodies, the integrity of thought: undiminished experience of the present disaster, wishfulness for renewed vitality and emancipatory alliance, and the exigency of critique are manifest in their necessary interactivity.

That Sholtz is not really on board with the Deleuzian program or "vision" becomes strikingly-yet quietly-evident as she dedicates the final

${ }^{20}$ Ibid., 17.

${ }^{21}$ At this point one can perhaps make out just how close to and just how far from Hirschhorn Sholtz is. The convergence and divergence of the political artistry of Sholtz and Hirschhorn would repay careful study.

${ }^{22}$ Late in the book Sholtz describes her work as "advocating" on behalf of Deleuze. I think this is a mistake.

${ }^{23}$ Consider in this connection the awkward attempts at achieving rhetorical charisma so frequently encountered among Deleuze acolytes. Sholtz's emphatic reserve reveals the Deleuzian mainstream as manically struggling to stay afloat atop of the depressive undertow and manifold complicities into which those who venture into Deleuzian waters find themselves dragged. (If it seems odd to speak of a depressive Deleuzian undertow, recall that Deleuze images a world teeming with transformative, truly novel possibilities blocked, or if not, for the most part recuperated, by the as if metaphysically mandated inertial forces of "opinion," etc.) 
section of the book to "find[ing] an example of art that actually contributes to the invention of a people ... and ... show[ing] how art and art practices can be a model for ... a people-to-come." 24 One might have thought on the basis of the foregoing that art as such, or at least a great deal of modern art, by provisioning novel affects and percepts, instigates a people-to-come. That finding an example of art practice that even models, let alone induces [activates], a people-to-come is evidently difficult suggests that the development of a people-to-come, even the clarification of the concept, is incredibly hard-won and dependent on socio-historical variables, hardly the automatic result of aesthetic experience or its social analogs. ${ }^{25}$ Actualizing a people-to-come is no "program for aesthetes." What this concluding gesture suggests is that release into a Deleuzian multiplicity of transformative and transforming affects and percepts, a world of minoritarian becomings and unrecuperated, eventful wanderings-generally, the fundamental elements of Deleuze's political ontology-remains for us a dim prospect, a frozen latency; ever available, and as such tantalizing, yet insistently impracticable. Facing up to this, Sholtz refuses the fantasy of explosive release endemic to the literature. What her reserve makes plain, however subtly and quietly, is that today one cannot simply be a Deleuzian, that (her) Deleuzian proclivities are unlivable, necessarily stunted.

With this in view, the critical significance of Sholtz's claim, following Heidegger and Deleuze, that art provides a privileged, amplified perspective on and simulates the development of a people-to-come comes into focus. That the socially marginal institution of art would be the primary, even necessary medium in which a people-to-come is simulated and perchance activated ${ }^{26}$

${ }^{24}$ Sholtz, The Invention of a People, 265; emphasis added.

25 Sholtz's treatment of Bacon and Klee should be reconsidered in light of this concluding effort. I take it that part of the claim here, or more precisely, the ultra-reserved intimation, is that Bacon and Klee are not adequate catalysts for a people-to-come at present, thus that the concept of a people-to-come is fully historical. Signaling in this direction, and very much to her credit, as noted, Sholtz consistently downplays Deleuze's metaphysical adventurism. Compare, inter alia, Elizabeth Grosz, Chaos, Territory, Art: Deleuze and the Framing of the Earth (New York: Columbia UP, 2008). The role of historicization in Sholtz's theorizing the configuration of aesthetics and politics might be amplified by comparison with Poggioli's The Theory of the Avant-Garde: "the hypothesis (really only an analogy or symbol) that aesthetic radicalism and social radicalism, revolutionaries in art and revolutionaries in politics, are allied, which empirically seems valid, is theoretically and historically erroneous." See Renato Poggioli, The Theory of the Avant-Garde, trans. by Gerald Fitzgerald (Cambridge, MA: The Belknap Press of Harvard University Press, 1981), 95.

26 "The affects of art ... prepare the sensibility necessary for the critical consciousness that is nomadology" (Sholtz, The Invention of a People, 255; emphasis added); "affects ... can have the effect of changing the possibilities that we then take up and live" (Ibid., 257; emphases added); "These potentials ....are selected according to situations and ostensibly created as an event of becoming" (Ibid.; emphasis added). Cf. Ibid. 251: "nomadology reveals a different way of being

(c) 2017 Adam Rosen-Carole

https://www.kritike.org/journal/issue 21/rosen-carole december2017.pdf

ISSN 1908-7330

(c) $)$ BY-NC-ND 
means that Deleuzian ideas are, like art, socially inessential, anything but live possibilities. Sholtz's suppressed thesis is that, sequestered to the outermost limits of social reproduction, for the most part isolated from the structures of domination they would contest, art practices, like Deleuzian ideas, remain a repository of emancipatory interests and provocations that cannot in any obvious ways be taken up and lived, practically realized. (Or the ways they can be taken up inevitably disappoint, e.g., remain "ethical" or "artistic," which is to say, socially secluded.) They persist, and indeed exert their romantic allure, by grace of their predominant social inconsequentiality. This is not to say that they without their effects, certainly. But it is to say that, for the foreseeable future, these effects will remain scattered and wildly outmatched by the forces of domination they are up against. If "the abstract machine and its lines of flight manifest in their most potent form through works of art," then these are hardly potent. ${ }^{27}$

in relation to space and others that can be incorporated and mobilized for political activity and change," hence is not itself immediately such (emphasis added).

${ }^{27}$ Sholtz, The Invention of a People, 145. While it would be pushing things too far to say that, for now, a people-to-come (as ethical alignment) resides merely in the City of God, just how much of an hyperbole this would be is not clear. Agreement in "tendency," in Walter Benjamin's sense of the term, does not constitute a polity. Cf. Walter Benjamin, "The Author as Producer," in New Left Review I/62 (July-August 1970), 83-96. Indeed, what would transfigure the ethical register of a people-to-come into political constitution is very much unclear in Sholtz as much as in Deleuze, though for different reasons. (It is not even clear if Deleuze is much interested in the question, and at times Sholtz seems averse to it; see, e.g., Sholtz, The Invention of a People, 268: "a minor politics or minor art ... would not and could not operate through the molar structures of legislation or policy." Part of my worry about this repudiation is that it risks relegating a people to come to a kind of neo-monasticism. While it is a signal feature of Sholtz's accomplishment that her performative elaboration of a people to come takes shape as an active mimesis of modernity's ongoing crisis, that is, of the fetishistic displacement of eros onto the cycle of frustration and longing itself rather than any possible object of satisfaction, if this is all that Deleuzian endless becoming comes to, all that a people to come comes to, we should be wary. Or to put the point in more contemporary terms: if one rejects the very question of how a population becomes a people, does one not concede to the reign of biopolitics? Or to put the point in somewhat more practical terms: if a people to come is insistently and overridingly an ethos of resistance, and all the more so to the extent that it is primarily an inceptive preparation, anticipation, projection, and imaging, then might it be, at a certain point, just us getting in our own way? When is a safe space-e.g., artistically mediated politics-an enclosure? For a counterpoint, see Sholtz, The Invention of a People, 271. For indeterminate treatments, see Ibid., 249 and 251. To be sure, Sholtz's reserve with respect to political projection is the price she pays, that perhaps must be paid, for sustained attunement to the present. A worry insists nonetheless-must this be the price paid?) What the reference to Augustine, however hyperbolic, allows us to appreciate, then, is the danger of moralism, indeed of moralism's easy but by no means inconsequential imperialism, in Deleuze, and in a different way, in Sholtz. From Cicero's notion of moral community ("Romans" everywhere united in their identification with or acceptance of the same laws/principles, which, for the most part, they have no hand in constructing) to Augustine's rendering of the City of God as authentic and true community there is not a great leap, and obviously a historical connection. At stake, in short, is the question of the de-politicization of a people-to-come: whether its constitution as, and thus its stranding as, merely ideological and abstract alignment (or

(C) 2017 Adam Rosen-Carole

https://www.kritike.org/journal/issue 21/rosen-carole december2017.pdf

ISSN 1908-7330

(c) BY-NC-ND 


\section{DANCING AFTER PHILOSOPHY}

Consider now that the artists relevant to articulating and perchance stimulating a Deleuzian people-to-come are, even within the sphere of art, exceptional: "Deleuze is drawn to artists of a particular ilk, those who live, breathe, and create on the boundaries of chaotic intensity, situating themselves within the maelstrom of psychic dissonance and cultural upheaval in congress with the unknown .... Deleuze attributes to certain figures, chiefly artists, special insight, an ability to move beyond the theatre of representation and engage in the movement of pure immanence." 28 The resources for a people-to-come are apparently quite rare. If such movement is so exceptional among artists, it can hardly be presumed to be generally practicable. Hence Sholtz's reserve with respect to her Deleuzian preferences. Her authorship embodies a difficult knowledge.

ephemeral alliance) is historically contingent or internal to the notion itself. Which is to ask: what practical and institutional shape might a people-to-come take? What would transform a population into a people (to come)? Or is the very idea of a people-broadly, the civic republican tradition-being abjured in the idea of a people-to-come? And to the extent that it remains a matter of ideological and abstract alignment, i.e., agreement in tendency rather than coimplication in extended praxis, to what extent is a people-to-come a force of imperialism?

Perhaps in part, Sholtz's reticence vis-à-vis the question of politics can be traced back to Heidegger's stance of emphatic, perhaps excessive, unknowingness about what politics-as democracy—would be (post "the turn"). For Heidegger, it seems, something-well expressed via the elusive and globally encompassing character of "techne"-is impeding collective selfrealization, i.e., politics. Something is blocked, eclipsed by an interactive complex of developments of planetary proportions. Correspondingly, at this stage of his work, political prohibition on preparation for a messianic age takes shape as a metaphysically inflected conception of Ereignis. For Heidegger, it seems, we know everything and nothing about what we want politically. This is registered in his work, and in Sholtz's, in the evidence and obscurity of "a people" (also of "politics" and "event"). The notion of "a people" as absent or deferred underlines our unknowingness with respect to our primary political desires; it is not that we lack political will (or not only that), but that we lack a coherent conception of what we want politically. That is, our imaginative and conceptual deficiency is sourced in a materialinstitutional deficiency. Both Heidegger and Sholtz may overestimate these deficiencies insofar as they suggest that we cannot but find ourselves preparing, anticipating, but unknowingly. [Heidegger's historicization of art as cognition in "The Origin of the Work of Art" might be relevant to this. See Martin Heidegger, "The Origin of the Work of Art," in Poetry, Language, Thought, trans. by Albert Hofstadter (New York: HarperPerenial ModernClassics, 1971), 15-86.] And in both cases, such overestimation may be motived by a desire, understandable even if perhaps reactionary, to thwart totalization: the deficiency becomes the ground of non-closure. In other words, overemphatic unknowingness with respect to the political may signal the legacy of trauma: hyperinvestment in uncertainty functioning as a continuation of and compensation for unclaimed experience, thus finding itself in the service of disavowal and imaginative reparation.

In connection with the issue of moralism flagged above, it would be interesting to compare The Invention of a People with two of Kristeva's works. See Julia Kristeva, Strangers to Ourselves, trans. by Leon S. Roudiez (New York: Columbia University Press, 1991). See also Julia Kristeva, Nations without Nationalism, trans. by Leon Roudiez (New York: Columbia University Press, 1993).

${ }^{28}$ Sholtz, The Invention of a People, 175.

(c) 2017 Adam Rosen-Carole

https://www.kritike.org/journal/issue 21/rosen-carole december2017.pdf

ISSN 1908-7330

(cc) BY-NC-ND 
This would not be reserve without struggle, without the intensity of inspiration and of indignation-following from unguarded experience of the present state of things-manifesting in occasional outbursts of untoward excess. For instance, there are moments in which Sholtz strays into glorifying deracination. ${ }^{29}$ Yet, even so, she steers clear of any anarchism. Consider the following: "Deleuze ... imagines a thinking that takes flight from the earth and a concomitant rhizomatics that frustrates both the rooted and the rootless, nomadic wanderings," 30 "the totalization of the war machine ... would amount to another kind of fascism. If the model of the war machine were extended to the entire earth, even to constitute smooth space, it would signify a totalizing and debilitating process of closure." ${ }^{31}$ Unable to hold herself back entirely from fetishizing Deleuzian thought-which is understandable and perhaps not such a bad thing, a minimum of fetishism providing a necessary counterweight to pervasive pressures toward indifference and incitements to despair-Sholtz remains critically circumspect: a fetishistic minimum in no way becomes charismatic social mandate or even zealous personal commitment. Yet her criticisms of Deleuze are often subtle, too subtle, as if she were hiding them from herself-or one part of her authorial persona were having its say, pressing its plaints and warning the readership, despite the inclinations of another. The struggle to sustain the difficult knowledge that her Deleuzian preferences are unlivable, necessarily and in part rightfully inhibited, is evidently arduous-itself an element of the self-conscious performance even if not entirely clear as such to the empirical author.

Examples of this too subtle, almost coded criticism-and thus of this struggle-abound. In the context of Sholtz's mention of the debate surrounding the status of the refrain in Deleuze's writings (some hold that nearly any refrain effects a productive displacement, while others, partially on the basis of Deleuze's manifest privileging of modernist music and painting, maintain that refrains in pop music especially tend to operate as monotonous forces of totalization-dead repetitions), her claim that "[ $t]$ he refrain which flows through Deleuze's writing is the affirmation of a liberating dis-organization" perhaps, quite discretely, becomes a way of saying that Deleuze is given to his own, i.e., internal, pop devolution. ${ }^{32}$ Slightly more explicitly, when Sholtz writes that "Gregor's deterioration in Kafka's Metamorphosis from human thoughts and expressions to

\footnotetext{
${ }^{29}$ Or, conversely, demonizing stasis: e.g., "assemblages become fixed and concretised, their essentiality unopposed, and this is a problem." Sholtz, The Invention of a People, 145. For an example of her occasional veering toward a very dangerous eroticization of flux, see Ibid., 250251.

${ }^{30}$ Ibid., 126; emphasis added.

31 Ibid., 253.

32 Ibid., 175 .
}

(c) 2017 Adam Rosen-Carole https://www.kritike.org/journal/issue 21/rosen-carole december2017.pdf ISSN 1908-7330 
incomprehensible, guttural noise is also an excellent image for the sliding scale of free indirect discourse and its power to reveal an inner seething of language, its murmuring, senseless materiality and the unformed material of expression," the undercurrent of critique (namely, of unbridled Deleuzism), indeed of warning, is unmistakable, however overshadowed by an appreciative attitude toward Deleuze's interests in anti-humanism, minoritarian literature as war machine, the asemiotic, etc. ${ }^{33}$ While avoiding polemics and perfunctory criticism is admirable, this is understatement pushed far too hard. It is as if a sensitive nerve were being respected, or demanding that it not be impinged upon; as if criticism of a still vital yet vexing source of inspiration were being quieted, suppressed just short of occlusion, in order that its negotiation be afforded the necessary time and space of its unfolding — as with "working through." 34

Sometimes, however, Sholtz's proclivity for understatement makes her criticisms of Deleuze all the more forceful. After outlining the Deleuzian criteria for a people-to-come, Sholtz notes that such an endeavor, however emancipatory in intent, risks "becoming reterritorialized as a method of fascistic control. Logically, as soon as a people is defined, it can be stratified and absorbed into regimes of dominance or state apparatuses - this is always a possibility, especially so in what Deleuze refers to as our contemporary 'control societies.' Moreover, this must be the case if one remains committed to a thoroughgoing immanence. In order to address this, Deleuze links the invective of deterritorialization to a political stance which corresponds to a particular typology and movement, which productively de-centres the polis by countering it with nomos in order to open a new space of conceptualisation and concept of space." 35 (249-50; see also p. 253). This is not much of an "address[ing]," and Sholtz knows this. Her criticism in this regard, while certainly understated and underdeveloped, arrives with a powerful thud. Here and elsewhere Sholtz raises the biggest, most damning problems for Deleuze's project, then glides through. ${ }^{36}$ There is a tacit or explicit

${ }^{33}$ Ibid., 178.

${ }^{34}$ Another place at which one might detect an excessively subtle criticism of and distancing from contemporary Deleuzian enthusiasm is in Sholtz's discussion of Philip Corner's Piano Activities. While Piano Activities is presented as a "paradigmatic example of ... revolutionary affect," Sholtz might be taken as intimating that the $60 \mathrm{~s}$ were the last best hope for Deleuzian artistic politics. See Sholtz, The Invention of a People, 271.

${ }^{35}$ Sholtz, The Invention of a People. 249-250, 253.

36 See Ibid., 252-253: "This undoing of things raises the difficult issue of political violence as constitutive of nomadology and the dilemma of creative destruction: 'Lines of flight ... are very dangerous for societies' (MP 250/204), yet they are also instrumental in producing a milieu in which change is possible." Here too Sholtz does nothing to relieve the worry she raises. The aporia is flatly stated, all the better to remain visible as blockage. Elsewhere, rather than dropping a daunting problem in our path, Sholtz delicately lays bare the perhaps insuperable

(c) 2017 Adam Rosen-Carole

https://www.kritike.org/journal/issue 21/rosen-carole december2017.pdf

ISSN 1908-7330

(c) $)$ BY-NC-ND 
acknowledgment of the dangers and inadequacies of Deleuze's project, but, remarkably, no fretting or maneuvering. (So too with her treatment of Heidegger and Nazism.) Sholtz makes plain a serious risk or devastating problem and then moves on, seeking neither to redeem nor to condemn, ${ }^{37}$ in part because she does not need Deleuze. Not as idol, in any case. Her achievement of thoughtful integrity renders her needless of a master, hence uninterested in the apologetics or denunciations by which better masters are wishfully called forth. Capable of autonomous experience, no doubt in part due to Deleuze's inspiring influence, Sholtz has no need for a master to obey and/or resist. To be sure, she needs Deleuze's continual inspiration in ways already mentioned, but what she needs she has internalized. (Much of her treatment of Deleuze is a coming to terms with this.) Deleuze's "vision" is, for Sholtz, a projection of possibilities, an imaging of resistance and emancipation, an opening, not a religion; not even a regulative ideal. What this dimension of Sholtz's authorship gives to be seen is the meaning of "overcoming." 38

In view of her criticisms of Deleuze, one might say that Sholtz's ultimate claim, taking a distance from Deleuze, is that art is capable of preparing us, perhaps forever, or until all availability to what it portends is

problems with the Deleuzian project, gently alerting us to the roadblocks inevitably encountered by those who would pursue the Deleuzian path. Such delicacy is equally forceful in result.

${ }^{37}$ In one particularly striking instance, Sholtz raises the most difficult, challenging questions, arguably the central questions that any advocate of Deleuze's aesthetic-political ontology would have to contend with, and then simply, strikingly moves on, never in the succeeding developments engaging, let alone answering, the questions she frames, as if implying that they are flatly unanswerable (at least by us, now): "'What kinds of invention does Deleuze's art imply?' ... 'what justifies Deleuze's view over any other?' How can one make the claim that one perspective on invention is more adequate than another, if there is no truth to any and we take his claims of immanence seriously? Is it merely the value of inclusion that guides Deleuze's judgment that Heidegger got the wrong earth, the wrong people?" Sholtz, The Invention of a People, 243.

38 Correlative to Sholtz's subtle yet highly significant criticisms of Deleuze is her consistently subtle reserve in affirming her Deleuzian preferences: "connections, flows and relations ... made through affect ... can be the inspiration for drawing creative intersections and new lines of development" (Sholtz, The Invention of a People, 252; emphasis added); "These potentials ... are selected according to situations and ostensibly created as an event of becoming" (Ibid., 257; emphasis added). Because they do not overwhelm her, Sholtz's Deleuzian preferences are evidently necessary openings, a medium of inspiration supporting the capacity for appreciative attention to low-key latencies within prevailing structures of domination. Or from a slightly different angle, one could say that within her authorship Deleuze's thought functions more as counterballast than as action-guiding ethical/political system, regulative ideal, or projected practicable program. Rather taking it as a platform to make overblown claims about art's political-ontological efficacy, which would be mere self-indulgence and critical retreat, Sholtz's treatment of the Deleuze material central to her interest in a people-to-come remains resolutely reserved, focusing steadily on art's political valence: its capacity for positive, creative, yet insistently marginal inspiration.

(C) 2017 Adam Rosen-Carole

https://www.kritike.org/journal/issue 21/rosen-carole december2017.pdf

ISSN 1908-7330

(cc) BY-NC-ND 


\section{6}

DANCING AFTER PHILOSOPHY

swamped by the stagnation of mortified life, for a politics that we cannot but, from this side things, hope for, but which we may not want, which we may rightfully refuse, if it ever comes..$^{39}$ In other words, that we do not know what we want.

This is an extremely compacted point in her authorship. So stridently does Sholtz refuse to surrender to Deleuzian enthusiasm that, in a way despite herself, she makes evident the impossibility of an unqualified affirmation of Deleuze's ethics/politics far more forcefully than even Deleuze's most trenchant critics. Yet her impassioned expositions of Deleuze make plain that she remains very much under his sway; more than charmed, if not fully committed. One crucial characteristic of these expositions, gesturing in both directions simultaneously, is its relative coarseness. In one way, the relative coarseness of Sholtz's treatments of Deleuze suggests that the material is, for her, too live, too fresh, raw: something not yet fully worked through, the site of an impassioning encounter in whose sway she remains and whose force she seeks to extend, a captivating influence that propels the discursive expression it also overwhelms. ${ }^{40}$ Somewhat choppy in its development of both individual concepts and conceptual movements, that is, breaking off and moving on before a concept or conceptual movement attains clarity and consolidation, Sholtz's treatment of Deleuze is imbued with the force of passionate immediacy — in part, a passion that needs to see where things are going; a passion at once to see and not to see. A gripping inspiration to which she would, if she could, give herself over, the Deleuze material is, for Sholtz, a site of investiture, indeed in some way a calling or charging, that she feels compelled to work out; though no fanatic, she is very much under Deleuze's influence. In another way, this relative coarseness of treatment suggests ambivalence: it is as though Sholtz were not quite convinced by her impressions of the extraordinary promise and value of Deleuze's thought, and so is not entirely committed to working through the material. In this connection, Sholtz's suppression of Deleuze's metaphysical interests assumes a new significance. Such coarseness perhaps betrays an anxiety from which it is, in a way, a release: as from a passion that, one senses, if granted free reign would disappoint or a commitment that one vaguely knows cannot be carried through. ${ }^{41}$ In short, the relative coarseness of Sholtz's treatments of Deleuze exhibits all the markings of unresolved attraction to

39 Cf. Andrew Hewitt, Fascist Modernism: Aesthetics, Politics, and the Avant-Garde (Stanford: Stanford University Press, 1993). This is one reason it is important that experimenting with the idea of a people to come occurs in the safe space of art.

${ }^{40}$ Whether and to what extent Deleuze's thought is intrinsically opaque cannot be considered here.

${ }^{41}$ Though consistent with it, this element of Sholtz's text is not fully integrated into her elegantly discomposed authorship.

(c) 2017 Adam Rosen-Carole

https://www.kritike.org/journal/issue 21/rosen-carole december2017.pdf

ISSN 1908-7330

(c) $)$ BY-NC-ND 
one who "one knows better" than to pursue. In both ways, Sholtz makes plain that her Deleuzian preferences are far from consolidated, let alone the firm ground of ethical/political prescription.

As reserved as Sholtz's authorship is, The Invention of a People is shockingly audacious-yet by no means virile or vituperative; to its great credit it avoids the aggressively masculine modalities of audacity so frequently encountered. Boldly but without a hint of self-arrogated authority or assuming a domineering tone, Sholtz concerns herself with nothing less than "reinvent[ing] philosophy," 42 "construct[ing] a new logos," 43 "the essence of humanity," 44 "re-open[ing] the question of art and the future of humanity," 45 and voicing an ethical/political "task for humanity." 46 (243; see also pp. 86 and 260). As astounding as the audacity of her topics is that in their pursuit her authorship maintains its remarkable reserve, never signaling a private ambitiousness or becoming overbearing. This is itself an exemplary artistic accomplishment; all the more so in that, unusually, none of this comes off as naïve. What's more, eschewing aggressively masculine modalities of audacity in no way involves the typical masochistic excess-especially prominent in the Heidegger and Deleuze literature. Sholtz's resolutely scholarly, indeed somewhat fastidious, treatments of her topics may seem somewhat excessive, perhaps nervous, but such an insistently scholarly attitude, like religion of old, structures ex-static inclination, forestalling super-ego imperativizing of masochistic self-dissolution or precipitous deregulation of discourse in order to be swept up in the strong winds of overpowering thought. Sholtz's performance is inspirited but not erratic or anarchically self-exalting; there is nothing of Honey's "I dance like the wind!" (a moment played brilliant by Sandy Denis in Mike Nichol's film rendition of Who's Afraid of Virginia Woolf?).

The formal endeavor and seeming paradox of the book, namely, the achievement of autonomous experience through reflective reconstruction of one's sources of philosophical inspiration, is also the book's most abiding thematic concern. At stake, one might say, is working through transference as a condition for experience. Further, analogous to Freudian practice, Sholtz would have us expect and prepare for, thus supports our capacity to undergo, to remain affectively and reflectively available to, the unexpected, which is to say, experience ${ }^{47}$ Formally/performatively and thematically, Sholtz asks how

${ }^{42}$ Sholtz, The Invention of a People, 4.

${ }^{43}$ Ibid., 171.

${ }^{44}$ Ibid., 87.

${ }^{45}$ Ibid., 48.

${ }^{46} \mathrm{Ibid} ., 243$. See also Ibid., 86, 260.

${ }^{47}$ Sholtz's methodological and performative privileging of the aleatory also might be considered in connection with the role of free association in psychoanalytic theory and practice. So too her understanding of the Deleuzian simulacrum, and the way this understanding takes 
not to destroy the possibility of experience through neglect or inadequacy, i.e., lack of form. "As thinkers of the event, both Heidegger and Deleuze are invested in presenting the conditions under which something new arises and in presenting a form of thinking adequate to these conditions." 48

Earlier I said that The Invention of a People is and must be engaged in reconstructing and comparatively evaluating the mutual mediations of ontology, philosophy of art, and ethics/politics in Heidegger and Deleuze, and now we are in a position to see why. The work of reconstruction and comparative evaluation is the medium of mourning, of overcoming, thus the condition for-the chance of-autonomous experience. Performatively, the work of divestment unfolds through a reconciling, which is to say, exceptionally attentive, well- and confidently worded, and structurally articulated, investment in the many details and overall significance of Sholtz's two primary sources of inspiration: Heidegger and Deleuze. Her mastery of the material is how she lets go.

This is especially evident in her treatments of Heidegger. ${ }^{49}$ Sholtz's writing on Heidegger is perfectly satisfying, saying neither overmuch nor too little for its purposes within the overall economy of her argument and altogether clear. ${ }^{50}$ Through this satisfying, and more importantly, confident, satisfied treatment, one senses that the object of Sholtz's consummate scholarly care is long divested, that the thoughtful, circumspect return (reconstruction) is in the service of working through so as to really give up what is already affectively distant, no longer really compelling or of orientational significance. As opposed to the typical antipodes of hysterical denunciation and somewhat less hysterical retrieval of an authentic philosophical core, a calm pervades Sholtz's writing on Heidegger as is only possible when one is no longer embroiled with an author as a vital medium of deeply engaging or mystifying problematics. Sholtz dares to be satisfied with Heidegger-to grandly, in the way of a once and for all type endeavor, work through his once and to some extent still inspiring interest until there is nothing left to say, and this becomes clear, thus until she can meet Heidegger,

shape in her authorial performance, might be thought in connection with features of the analytic setting in the service of provoking and analyzing transference. Indeed-though this point is peripheral to both Sholtz's central purposes and my own-the simulacrum may be the pivotal framework allowing for a Deleuzian reconciliation with psychoanalysis; or for identifying the elements of caricature in Deleuze and Guattari's animadversion to it and the anachronisms of the contemporary reassertion of their contempt for it.

${ }^{48}$ Sholtz, The Invention of a People, 15.

49 This is also a highly significant factor in the differences in quality of Sholtz's respective treatments of Heidegger and Deleuze.

${ }^{50}$ One could certainly differ with her interpretations, but that is beside the point.

(c) 2017 Adam Rosen-Carole

https://www.kritike.org/journal/issue 21/rosen-carole december2017.pdf

ISSN 1908-7330

(c) BY-NC-ND 
whatever his philosophical majesty, on even terms. ${ }^{51}$ The reconstruction attains its perfection, and therewith its sense of closure, on the condition that the object of interest is no longer a gateway into a field of unresolved, compelling questions and intriguing problematics, no longer a vital interest. Audaciously, what this reconstruction gives to be seen is Heidegger thought through-that Heidegger can be thought through, learned from and separated from. The treatment of Heidegger is (performs) not a rationalization of affect, i.e., an apologetic for overpowering inspiration, but a rational continuation and amplification of the affects involved in loss and mourning in the service of overcoming. Hence, the sense of holiness or of the sacral (i.e., untouchable) in Sholtz's writing on Heidegger: mourning is not to be disturbed, let alone corrected.

Of course, Sholtz's reconstructive working through of Heidegger is not only in the service of divestment and separation. Within the structuring choreography of her performance, the memory of Heidegger remains constitutive, an enabling condition for her singular engagement with Deleuze and, ultimately, her autonomous performance itself. Only by transforming the ghost of Heidegger into an ancestor can Sholtz work through Deleuze and thereby come into her own. ${ }^{52}$ More directly stated, Sholtz needs Heidegger, and her mourning of Heidegger, and the dark memory of Heidegger's politics, to open the Deleuzian path that she does not take but explores-i.e., experiments and seeks to come to terms with, attempts to concretize and clarify, does not so much navigate, let alone launch herself down, as intellectually map out, tracing the terrain, probing it from afar. ${ }^{53}$ The consummate composure and calm that Sholtz achieves in her treatment of Heidegger becomes the productively sedentary energy and centeredness that tempers her clear preferences for Deleuze's pre-individual, impersonal,

${ }^{51}$ In no way does Sholtz's treatment suggest that there is no more work to be done with or on Heidegger, only that whatever interest there may be is not her concern, or at least not an overriding, exigent concern.

52 "Those who know ghosts tell us that they long to be released from their ghost life and led to rest as ancestors. As ancestors they live forth in the present generation, while as ghosts they are compelled to haunt the present generation with their shadow life .... Transference is pathological insofar as the unconscious is a crowd of ghosts ... this is the beginning of the transference neurosis ... ghosts of the unconscious, imprisoned by defenses but haunting the patient in the dark of his defenses and symptoms, are allowed to taste blood, are let loose. In the daylight of analysis the ghosts of the unconscious are laid and led to rest as ancestors whose power is taken over and transformed into the newer intensity of present life, ... secondary process, and ... contemporary objects." See Hans Loewald, "The Therapeutic Action of Psychoanalysis," in Papers on Psychoanalysis (New Haven: Yale University Press), 249.

experimentation."

53 Cf. Sholtz, The Invention of a People, 259: "The encountering of artworks is

(c) 2017 Adam Rosen-Carole

https://www.kritike.org/journal/issue 21/rosen-carole december2017.pdf

ISSN 1908-7330

(cc) BY-NC-ND 
cosmic forces and disturbances. ${ }^{54}$ Conversely, her Deleuzian passion affords her a critical vantage on Heidegger and projects a line of flight by means of which she takes leave of him, releasing herself from embroilment with a powerful, but for her no longer productive, body of work. Within the construction of Sholtz's authorship, Heidegger and Deleuze thematize and carry out "a polemos, a struggle between separation and belonging together." 55

Sholtz's treatment of Deleuze, in contrast with her treatment of Heidegger, is marked by an infatuation that requires a different manner of working through. Though her engagement with Deleuze, too, is a coming to terms with limits and in the service of divestment, far more emphatically than is the case with her treatment of Heidegger, such divestment is made possible by giving Deleuze his best chance to be compelling. It is as if Sholtz is romancing Deleuze. Though clearly inspired by his work, she does not know quite what to do with him, how to live with or situate him. Deleuze projects a compelling emancipatory vision, but Sholtz cannot but worry about its practicability and violence. ${ }^{56}$ So she does what lovers do: gives the beloved every chance while trying to remain as clear-sighted as possible.

In terms of pure aesthetic delectation, Sholtz's writing on Heidegger is so much better than her writing on Deleuze because she is not yet done with Deleuze, is still enduring his influence, thus writes in a way that suggests a mildly intoxicated disarray, an unmastered, propelling interest. About Deleuze Sholtz is undecided-and this is what her authorship gives to be seen. (She is clearly decided that Heidegger is great, but a "precursor"; therefore whatever unfinished business she might have with him is shuffled onto her relationship to Deleuze.) Because she is more than intrigued yet critically reticent-in sum, because she is ambivalent-Sholtz's discussions of Deleuze, unlike those of Heidegger, are a bit conventional and at times jargony. Or better, the sometimes conventional and jargonistic character of her writing on Deleuze is how the unresolved-passionately animated but critically reserved-character of her relationship to Deleuze manifests itself. As much due to her passion as to her critical vigilance, Sholtz is not at all clear about what she wants to do with Deleuzian ideas, what can be done with them. Hence the occasional unclarity of phrasing. ${ }^{57}$

None of this is intended as critique. Indeed, there is something right about the kind of writerly lapse that occurs in relation to the Deleuze material. Who knows what to do with these ideas? That many, especially in the artworld,

54 In some ways, and worryingly, the dialectic of Heideggerian gathering and Deleuzian displacement resonates with Rancière's police/politics dichotomy. However, cf. Sholtz, The Invention of a People, 126.

55 Sholtz, The Invention of a People, 192-193.

${ }^{56}$ Ibid., 254.

${ }^{57}$ See $i b i d ., 141$.

(c) 2017 Adam Rosen-Carole

https://www.kritike.org/journal/issue 21/rosen-carole december2017.pdf

ISSN 1908-7330

(cc) BY-NC-ND 
act as if they know exactly what to do with Deleuze is to the point. One measure of the remarkable accomplishment of The Invention of a People is that even its disappointments and frustrations are for the most part informative, worth more than a shelf of Deleuzian literature. Sholtz's writerly lapse is, even if symptomatically so, a rewarding medium of insight. Albeit perhaps too subtly, or even unconsciously, yet confluent with her authorship generally, what the conventional and jargonistic elements of Sholtz's writing on Deleuze performatively indicate is that it is not at all clear if Deleuze is to be taken seriously. The fault in the writing may reflect the fault in the object, as if obeying Aristotle's dictum to achieve only as much clarity as the subject matter admits. It may be that what stymies Sholtz's rhetoric and obstructs the development of her exegeses, causing them occasionally to collapse into conventionalism and cliché, is that there is not enough to work with, that Deleuze may be, at least to some extent, no more than faddish cliché fodder. ${ }^{58}$ Of course this is not Sholtz's dominant attitude toward Deleuze but rather a highly guarded moment of extreme reticence: a defensively contorted expression of a stratum of worry made inadmissible by her passion. What makes it possible, however, is the unguarded availability to experience that her authorship embodies generally. This writerly lapse is perhaps not so much error as the indirect expression of an exemplary availability to experience; disarray and slipping into cliché may be, even if they are not entirely so here, elements of a performance of autonomy..$^{59}$

${ }^{58}$ Consider that, more generally, perhaps despite herself yet consistent with her authorial performance of autonomous experience, Sholtz lets the murkiness, availability to obscurantism, and taint of magical thinking in Deleuze be seen remorselessly. Deleuzism may be bad metaphysics: if it is, giving it to be seen as such is preferable to affected airs of sophistication. To be sure, elements of Deleuze's thought are surely worth development, but not necessarily Deleuze's predominant form of treatment of these elements. In this respect, Deleuze is much like Hegel. Indeed, cherry picking from the former may feel compelling just as long as—or even in some ways because — cherry picking from the latter remains prevalent.

${ }^{59}$ While masochism is anything but the leading trait of Sholtz's authorship, that these writerly stumbles are not integrated and developed in the construction of her authorship despite their consistency with it may point to something like a success complex: a tendency to ruin one's accomplishment for fear of whatever the idea or fantasy of accomplishment is freighted with.

While straying into cliché seems, in the examples I have in mind, unintentional, knowingly engaging cliché is a condition for her work; thus judgment about these matters will be difficult. Sholtz must engage and slightly modify, i.e., augment, Deleuzian and Heideggerian clichés in order to maintain her thoughtful reserve; she offers not wholly new readings but slight adjustments, modest new pacings. Her accomplishment, one might say, is to reterritorialize the refrain; cf. Gilles Deleuze and Felix Guattari, Mille Plateux (Paris: Minuit, 1980), 369ff. "The painter is always involved in a process of selection, limitation, and elimination of some or all of the clichés with which she finds herself confronted, and this process is a struggle, requiring the painter to devise means to combat the relentless onslaught of clichés and take pains not to fall back into the world of re-presentation or imitation (FB, 83-4/71-2)." Sholtz, The Invention of a People, 151. In other words, a more generous reading than mine is possible.

(C) 2017 Adam Rosen-Carole

https://www.kritike.org/journal/issue 21/rosen-carole december2017.pdf

ISSN 1908-7330

(cc) BY-NC-ND 
The primary way of overcoming Deleuze, however, is through the poise, reserve, and gracefulness of Sholtz's authorship. The Invention of a People in no way embodies Sholtz's Deleuzian preferences. For Deleuze, "The moment of liberation/dissipation," which is "nothing less than the possibility of thought itself," "is equally a dis-organization, an involution which frees affects and speeds and plunges the ego into chaotic intensity." 60 This is clearly contradicted by Sholtz's authorial performance. Tempered and composed, Sholtz's authorship does not so much refuse as elegantly sidestep Deleuze's injunction to "Stop thinking of yourself as an ego (moi) in order to live as a flow (flux), a set of flows in relation with other flows, outside of oneself and within oneself' (ECC, 51/68)."61 And importantly, after ventriloquizing Deleuze's call for radical self-dispossession, Sholtz adds the quiet qualification: "but equally important is what one encounters." 62 Amidst a

However, this seems a good enough point at which to call attention to an objectionable aspect of the text/performance. If anything is objectionable in The Invention of a People, it is the occasional concession to inferior voices, i.e., citations of commentators whose language, juxtaposed to Sholtz's, is far too obvious and unrefined: like a dull mallet enforcing public opinion or a flimsy play gavel ceremoniously pronouncing feeble judgment, i.e. playing at Oedipal self-assertion. This is like inviting middling newspaper column reviewers onto stage amidst a compelling performance: such a self-important, unseeing, and cliché stuttering chorus has no place here. One almost wants to write this off as parody. When contemporary commentators are cited, as if their formulations were more elegant or incisive, it almost reads as mockery, especially in the case of commentators whose rhetorical modality is a gun-slinging macho "conciseness." See Theodor Adorno, "Punctuation Marks," in The Antioch Review 48:3 (1990), 300-305. Unfortunately, this isn't so. At best, what such citations make evident is that the various ideas Sholtz paces out so eloquently are already common sense (vulgar), thus that the significance of such pacing is its quality of movement, not any claim to conceptual or exegetical innovation or discovery. It is not unique ideas but unique treatments that matter. At worst, one might say that there is something mildly hysterical in Sholtz's citation of, let alone collaboration with, such fumbling, vagabond commentators as Lawler and Haar. Fortunately-though this hardly makes amends for the lapse in judgment-when Sholtz's "we" or "us" invokes such commentators in what is perhaps a fit of hysterical meekness, it simultaneously, through the power and acuity of her voice, pushes them away. That is, in moments of paraphrase, continuation, or summary following such citations, Sholtz's "we" becomes an amplified "I" or royal "we" speaking for and in the place of rightfully humbled inferiors. However, even this smack of Oedipal rivalry. It may be that Sholtz is given to surprise by the startling power and singularity of her voice, and when bad conscience sets in, she appeals to the flat-footed coarseness of contemporary commentators to alleviate the anxiety of her spritely serious singularity. So, I must qualify an earlier statement: Sholtz refuses nearly every mental refuge.

In comparison with this periodic submission to the authority of the vulgar, the occasional hitting of a false note and her somewhat fastidious, nervous manner of citation-it is as if she wants to keep fast company, or is even a bit delusional: the delusion being that this is a book for scholars who would be interested in checking translations against authoritative original language editions; Deleuzians especially, and the Heideggerians who might tolerate or seek out the company of Deleuze, are hardly that-is not so much objectionable as disappointing.

${ }^{60}$ Sholtz, The Invention of a People, 174.

${ }^{61}$ See Ibid., 173.

${ }^{62}$ Ibid., 173.

(C) 2017 Adam Rosen-Carole

https://www.kritike.org/journal/issue 21/rosen-carole december2017.pdf

ISSN 1908-7330

(c) $\mathrm{BY}-\mathrm{NC}-\mathrm{ND}$ 
storm of unsupportable enthusiasm for wild discomposure, Sholtz's authorship maintains its noninsistent yet emphatic and impacting composure. No "vibratory elements of language ... burst forth." 63 There is no "de-centering the authorial function ... unearthing ... senseless murmurings and incomprehensible utterances within language," nothing "wretched and stilted," 64 no "musical warbles." 65 Rather than submitting itself to semiotic overflow, Sholtz's authorship maintains its elegant self-possession. Its fundamental principles are immeasurably distant from those of "Absurdism, Dada, Futurism, Surrealism, Theater of Cruelty and Situationism." 66 And there is no hint of expressionism-nothing punctuating through a too harmonious, placid surface.67 However much intrigued by Deleuze's injunction that thinking "remain within intensity ... sustain the plateau wherein one experiences oneself as perpetually fragmented," Sholtz never goes in for "hyperconceptualization, layerings upon layerings of ideas forming an intensive matrix that is almost too much to bear: 'drawing together a maxim of disparate series (ultimately, all the divergent series constitutive of the cosmos)' (DR, 159/121)." 68 Of course, there are elements of erotic excess, a certain loss of control, in Sholtz's writing on Deleuze, but her authorship manages not to be overwhelmed by them. Never given to revolutionary outcry, and perhaps thereby slipping free of the depressive undertow of Deleuzian thought from out of which the compensatory extravagance of revolutionary rhetoric perhaps wrests itself, Sholtz's authorship remains qualified, reserved. E.g., "Through its multiple outlets and points of connection, literature has the potential to be a disruptive force that cuts through [rather than dislodges or undermines] the dominant (majoritarian) language, devising new and deviant uses (experimentation), and

${ }^{63}$ Ibid., 140.

${ }^{64}$ Ibid., 178.

${ }^{65}$ Ibid., 271.

${ }^{66}$ Ibid., 182.

${ }^{67}$ Just how far Sholtz is from any Deleuzian fetishism of the new, and of Deleuze's axiomatics and methodology, is shown not just by her methodological and performative commitment to analogy and eminence — though this is crucial— but even more directly by the graceful demurral by which she refuses measurement by such criteria as the following: "A philosophy's power is measured by the concepts it creates, or whose meaning it alters, concepts that impose a new set of divisions on things and actions." See Gilles Deleuze, Expressionism in Philosophy: Spinoza trans. by Martin Joughin (New York: Zone Books, 1990), 321. Her never austere, impassioned composure is a genuine rival to Deleuzian expressionism. Yet this is at once evidence of just how close Sholtz is to the Deleuzian sense of Spinozism that, ironically, Deleuze's optimism inhibited-performatively_in his own work: so insistent was Deleuze that thought is and must be practical that he neglected to develop, or more adequately realize, an expressivepractical authorship; for such can be done only by virtue of awareness of one's historical-political situation, which task Deleuze to a great extent rebuked, instead abstractly affirming an ideology of practice.

${ }^{68}$ See Shotz, The Invention of a People, 228.

(C) 2017 Adam Rosen-Carole

https://www.kritike.org/journal/issue 21/rosen-carole december2017.pdf

ISSN 1908-7330

(cc) BY-NC-ND 
opening political spaces." 69 While inspired by Deleuze, Sholtz holds back from any undue optimism, attending the fleeting possibilities projected by Deleuze's ethical/political "vision." Deleuze's political ontology of art is never described as offering more than openings, the possibility of the new. ${ }^{70}$ And even then, Sholtz underscores the aspects of Deleuze's thought that speak to the insuperable limits of innovation. E.g., "nomadology reveals a different way of being in relation to space and others that can be incorporated and mobilized for political activity and change. It offers a way of living outside the model of the state apparatus, which preserves itself vociferously through domination and control of spaces to make social order and rule intractably sedentary"; 71 "the possibility of thinking otherwise comes from the exteriority of the non-discursive. The path to escape is the pathic, as anterior to discursivity, though in constant complication with encodings, identifications, territorializations." 72 Deleuze is never so enthusiastically promoted as to need tempering by a great deal of explicit attention to the dubious and dangerous elements of his thought-much remarked upon anyway, and so redundant for one such as Sholtz who undertakes no commitment that would urge her to deny or diminish them. Thus, she lets all that is dubious in Deleuze's thought appear, most often without discussion-in quiet qualifications and moments that hit with a thud but are never followed by any prolonged fretting or needling. And through her graceful refusal to fall in line with the rhetorical trends of contemporary commentators, thus through all that is explicitly eschewed, not said, she speaks volumes. ${ }^{73}$ Sholtz's silence is eloquent and powerful: there is not a single argument for any Deleuzian conviction, and this implies, among other things, that we cannot argue our way into another mode of being, that the metaphysics (as such) just doesn't matter.

What this overcoming makes possible is the possibility of experience itself. (The performative displacement of the transcendental horizon in favor not of immanence metaphysically construed but rather social-historical presentness is an enormously important undercurrent of Sholtz's authorial

\footnotetext{
${ }^{69}$ Ibid., 137; emphasis added.

${ }^{70}$ Other commentators may be more fidelitous to Deleuze and Guattari's thought, e.g., Elizabeth Grosz in Chaos, Territory, Art: Deleuze and the Framing of the Earth, but this is ultimately to Sholtz's credit; she subdues the anti-phenomenological metaphysics of the percept, affect, and sensible itself- - especially the category of eternity — in order to write about the only aspect of Deleuze's thought that might matter: its treatment of the possibility of the new. See Sholtz, The Invention of a People, 149-150.

${ }^{71}$ Sholtz, The Invention of a People, 251; emphasis added.

72 Ibid., 259; emphasis added.

${ }^{73}$ As Adorno says, "the untruth can be recognized by its bloated nature." See "The Jargon of Authenticity," trans. by Rodney Livingstone in Can One Live after Auschwitz? ed. by Rolf Tiedmann (Stanford, California: Stanford University Press, 2003), 167.
}

(c) 2017 Adam Rosen-Carole

https://www.kritike.org/journal/issue 21/rosen-carole december2017.pdf

ISSN 1908-7330

(c) BY-NC-ND 
performance.) Through the mediations of her authorship, Shotlz's Deleuzian passions bear her not naively beyond but resolutely into the difficulties of the present. Within the scope of Sholtz's authorship, Deleuze images not a metaphysically secure other realm of infinite becomings subtending and compensating for the stasis and depredations of the status quo, and into which we might tap or immediately plunge, but multiple, infinite resistances to domination that are all eventually, indeed quickly, overcome. Exuding within and troubling what dominates them, such resistances are unable to break the spell of domination. A people to come is not a force of redemption, a harbinger of rejuvenation or reactivation and vindication of authentic principles historically betrayed and occluded. It is not an inaugural force of epochal transition, capable of emancipatory release from a repressive, stagnant actuality. It is, in a way, but an optics, or better, a disposition of affective and reflective sensitivity (not quite a practice), through which the nonexhausted energies of the present present themselves. In this respect, Sholtz's performative elaboration of a people to come is an updating of Heideggerian "preservation." Sholtz's Deleuzian passions, then, are the medium not of naïve or desperate enthusiasm but of awareness that we are not yet, and are unlikely to soon become, sufficiently available to, sensitive to, the plane of immanence; more precisely, that to a great extent immanence is historically-practically foreclosed, hence for the most part experiencedistant. Within the space of Sholtz's authorship, Deleuze conduces to the experience-the suffering-of the non-experience of immanence, of its distance from contemporary experience having become so extreme that it might be thought metaphysical. Only because it never becomes a subjective principle of her performance can historically objective despair be registered, paradoxically, through Sholtz's Deleuzian passions. ${ }^{74}$

From another angle, as configured within Sholtz's authorship, these Deleuzian passions are precisely what invest and amplify the minor accomplishments, hence the ongoing transformative possibilities, of present practices. Impressive strides are being taken in any number of domains. As ephemeral and endangered as they may be, even understood to be inevitably absorbed and neutralized by prevailing structures of domination, resistance and initiative are not yet exhausted, and this is what Sholtz's authorship gives to be seen and appreciated. ${ }^{75}$ Despite the prevalence, indeed nearinevitability, of the state machine and suchlike molarizing, dominating

${ }^{74}$ In regard to the progressive self-explication, i.e., self-consciousness, of Sholtz's performance, see Sholtz, The Invention of a People, 85: "we must be able to experience our distress."

${ }^{75}$ See especially Ibid., 257.

(c) 2017 Adam Rosen-Carole

https://www.kritike.org/journal/issue 21/rosen-carole december2017.pdf

ISSN 1908-7330

(cc) BY-NC-ND 
structures absorbing and profiting from resistance, ${ }^{76}$ something remains unexhausted. This is not a question of unwitting structural transformation through the dialectical recuperation of resistance but of attending an endangered but not extinguished remainder-a question of remaining present to persistent, innovative practices of resistance and emancipatory alliance that are not without consequence and that may image another form of being. Here Deleuze meets Adorno. ${ }^{77}$ Rather than projecting a people as a far-off fantasy or as abstractly other to prevailing forms of domination, Sholtz, via Deleuze, keeps experience keyed to the non-exhaustion of emancipatory movements in the present, however micropolitical or interstitial they may be. Its poised-affected, moved, in a way readied, but reserved-acknowledgment of the dynamic but hardly "mobilized" present, its tacit sidestepping of cynical diminishment, precipitous celebration, and rallying polemics, is how this authorship performs the integrity of thought, which is itself the sustaining of experience. Evidently and exemplarily solicited - which is to say, both called upon and shaken up-by all manner of contemporary accomplishments, but holding to its own path of reflective inquiry, Sholtz's authorship knows not what the next step for philosophical practice can be; and refusing the relief of fantasmatic actionism or antiintellectual self-deprecation, it sustains this unknowingness as the condition for and conduit of experience, and thereby sustains the possibility of philosophical practice itself: something distinct from work within the disciplinary enclosure of philosophy. ${ }^{78}$ Sholtz's authorship is a sounding of present practices, an effort to take one's bearings from and within them. By virtue of its impassioned reserve, Sholtz's authorial performance raises the question-which is itself an "overcoming" of Deleuze-of who we are in view of Deleuze's demands on who and/or what we must become if we are to be free..$^{79}$ Only through their mediation by her authorial performance do

76 " $[T]$ here is always the possibility, and in many respects the inevitability, that the war machine will be appropriated for the state apparatus, thus immobilizing its affects and rendering a method of control tout court." Ibid., 253.

${ }^{77} \mathrm{Cf}$. Ibid., 252. The suggestion here is that, for all their undeniable differences, the Deleuzian simulacrum (mediated by Sholtz's authorship) and Adornoian semblance converge. Another respect in which Adorno and Sholtz's Deleuze might be thought together is in connection with the question of immanent critique. Sholtz's Deleuze is not quite an advocate of unlimited affirmation, and in not being so, converges with the concerns of immanent critique to remain unabashedly, non-dialectically immanent.

${ }^{78}$ Cf. Ibid., 170: "Deleuze insists that art only prepares or forewarns of a people-tocome, rather than providing its model. The future of philosophy calls us to think through new affects, to think the pure being of sensation, in order that a new thinking and a new people emerge" (emphasis added).

${ }^{79}$ Compare Ibid., 255: "Art is ... a fundamental power of invention, which has the power to go beyond reality and hold open the question of what could be and what kind of beings we could be." Sholtz does not develop or configure the question of who and how we might be,

(C) 2017 Adam Rosen-Carole

https://www.kritike.org/journal/issue 21/rosen-carole december2017.pdf

ISSN 1908-7330

(c) $)$ BY-NC-ND 
Sholtz's Deleuzian passions conduce to the essential question: What would it be for immanence to become praxis? 80

One way to think about The Invention of a People is as a late rejoinder to Laclau and Mouffe's Hegemony and Socialist Strategy (1985) ${ }^{81}$ on the ground of newer "new social movements." One might then say that in view of recent political experiences, Sholtz proposes the rhizome rather than the chain of equivalence, nomadicism rather than hegemony, hope rather than fear (i.e., threat construction). But of course, and importantly, Sholtz does not propose these terms as replacements for Laclau and Mouffe's theoretical apparatus, let alone seek to displace their political experiences and interests with those of more recent vintage. While Deleuzian terms may be more adequate to contemporary political developments, or certain among them, Sholtz never argues for or polemicizes on behalf of their categorical superiority. In fact, she does not argue for them at all, or even "propose" them if by this is understood advocacy seeking the authoritative public institution of its initiatives. Rather than indulge in a fantasy of philosophical legislation or activism, i.e., "take a position," Sholtz experiments-somewhat

but holds open, via affect, the space of this question - which, if so doing is the accomplishment that Sholtz makes it out to be, must be imperiled, on the verge of collapse. Art, e.g., Sholtz's authorship, at once throws us ahead of ourselves and brings us into critical contact with ourselves by providing an encounter with affects with which we are incommensurable, affects that cannot be presently processed, either subjectively or cognitively: these are minor-to some extent diagnostic-disturbances.

${ }^{80}$ Let us note, in passing, another respect in which the work of reconstruction makes possible autonomous experience. The reconstruction of Heidegger and Deleuze affords Sholtz an imaginary heritage that supports the minimal self-stabilization necessary to undergo and reflectively sustain experience-especially such difficult regions of experience as Sholtz undertakes to explore. One dimension of Sholtz's "we" is clearly a generational transmission from Heidegger to Deleuze to herself. One might think, more, that this "we" echoes with a particular imaginary frame of transmission: from grandfather (Heidegger) to father (Deleuze) to daughter (Sholtz). The plotline is familiar enough: the enormously admirable, pathbreaking but somewhat conservative grandfather bequeaths a radical son who continues the work of the prior generation, though, partially due to his defiantly idiosyncratic idiom in which of course he is unwittingly identified with the past there where he would insist most vociferously on his independence, this legacy remains largely unknown until the arrival of the dutiful/undutiful daughter who sorts out the family legacy: she corroborates the father's criticism of his father but also underscores the legacy he is reticent to admit, identifies what is incomplete and insupportable in her father's work, and on this basis makes her own contribution. Even if this construction of an imaginary heritage is defensive, it is by no means pathological. And importantly, this imaginary heritage is in part what grants Sholtz- - how Sholtz grants herself- permission to be affected, exposed, even a bit wild, and in that thinking; for this is the family legacy. Even more, the particular history of philosophy told through the reconstructions of Heidegger and Deleuze is not only self-clarifying, and as such, self-stabilizing, it perhaps contributes to the confidence necessary to undertake the adventure of autonomous experience: if these figures and this history can be reflectively contained and articulated, anything can be.

${ }^{81}$ Ernesto Laclau and Chantal Mouffe, Hegemony and Socialist Strategy (London: Verso, 1985).

(C) 2017 Adam Rosen-Carole

https://www.kritike.org/journal/issue 21/rosen-carole december2017.pdf

ISSN 1908-7330

(cc) BY-NC-ND 
adventurously-with these terms, puts them into play and tests their resonance. In consequence, if one considers The Invention of a People to be a late rejoinder to Hegemony and Socialist Strategy, then by virtue of its critical but cautious, thus self-critical engagement with Laclau and Mouffe's postMarxist classic, it leaves us with an open question: What politics is right for us today-if there is one? ${ }^{82}$ As Gadamer says of our relationship to art: our intuitions cannot but be conflicted. One the one hand, we feel that autonomyinclined experimentation is frustratingly formalist, that in view of the exigencies of the moment, art should address our moral and political concerns. On the other hand, we feel that abstract and dissonant works are authentically moving, valid, and that art's attempt at direct political intervention is never far from philistine preaching. Thus, we feel that a middle position between the extremes of autonomy and activism is unavoidable, yet find it inevitably unsatisfactory. It is not just that a middle position betrays the ideals represented by the extreme antipodes but that activist art remains aesthetic while autonomous art cannot but be politically and ideologically freighted. So again, neither path seems quite right and a middle road is none the more satisfying. Failure is endemic to art. Similarly, in a political register, one might say that hegemonic consolidation and nomadic wandering are equally compelling and equally unsatisfying, and that a middle position, while unavoidable, cannot but disappoint. That Sholtz's question-What politics is right for us today, if there is one?-is left open is how it remains in touch with the contemporary, how it manages to stay true to the reality of dissatisfaction and uncertainty. ${ }^{83}$ Sholtz takes the temperature of the contemporary and does not lie: this alone is a significant accomplishment-to refuse fraud.

In its sustained exposedness to experience, its dancerly autonomy, The Invention of a People is the voice of the age. It is unwavering in its hopefulness but not unaffected by objective conditions of despair-modern tyrannies, unbridled capitalism and consumerism, the rampant destruction of thought, etc. Performatively holding open a taught space, ever on the cusp of collapse, Sholtz makes possible an experience of the present, and this is a rare accomplishment indeed. This is why, however cautious one must be about it, her holding onto Deleuze is so important. The hope he inspires, facilitated by the experiences of unexhausted ethical/political initiative to which his thought-when properly mediated-conduces, counters the objective despair of the present. But also, within the space of Sholtz's authorship, Deleuze's thought (one would never have expected this!) becomes a way of registering the destitution of the present, philosophically and

82 Cf. Sholtz, The Invention of a People, 260.

83 Cf. In this connection the discussion of threefold responsibility, especially with respect to the tension between the second and third planks can be found in ibid. 259 .

(c) 2017 Adam Rosen-Carole

https://www.kritike.org/journal/issue 21/rosen-carole december2017.pdf

ISSN 1908-7330

(c) $)$ BY-NC-ND 
politically. Through Sholtz, the question Deleuze addresses, in the wake of Heidegger, is this: Is nontotalization, both generally and in particular, politically, even coherently, thinkable?

Remarkably, Sholtz's performance makes of philosophy a transitional object. What she offers, philosophically and politically, is "just enough of a framework to ward off chaos and enough openness to allow movements to proliferate." 84 What she offers, in other words, is her independence of thought, her exemplary capacity for experience. This is what "public philosophy" should look like, and feel like. Sholtz's accomplishment is "to be equal to the conditions of life." 85 Elle est absolument moderne.

Department of Philosophy, Rochester Institute of Technology

United States of America

\section{References}

Adorno, Thedoro, Critical Models: Interventions and Catchwords, trans. by Henry W. Pickford (New York: Columbia University Press, 1998). "Punctuation Marks," in The Antioch Review 48:3 (1990). "Resignation," in Critical Models, trans. by Henry W. Pickford (New York: Columbia University Press, 1998). "The Jargon of Authenticity," trans. by Rodney Livingstone, in

Can One Live after Auschwitz? ed. by Rolf Tiedmann (Stanford, California: Stanford University Press, 2003).

Benjamin, Walter, "The Author as Producer," in New Left Review I/62 (JulyAugust 1970).

Deleuze, Gilles, Cinema 2: The Time-Image, trans. by Hugh Tomlinson and Robert Galeta (Minneapolis: University of Minnesota Press, 1989). Expressionism in Philosophy: Spinoza trans. by Martin Joughin

(New York: Zone Books, 1990).

Deleuze, Gilles and Felix Guattari, Mille Plateux (Paris: Minuit, 1980).

Fried, Michael, Absorption and Theatricality: Painting and Beholder in the Age of Diderot (Berkeley, University of California Press, 1980). Art and Objecthood: Essays and Reviews (Chicago: University of Chicago Press, 1998). Why Photography Matters as Art as Never Before (New Haven: Yale

University Press, 2008).

${ }^{84}$ Sholtz, The Invention of a People, 279.

${ }^{85} \mathrm{Ibid}$.

(C) 2017 Adam Rosen-Carole https://www.kritike.org/journal/issue 21/rosen-carole december2017.pdf ISSN 1908-7330 
Grosz, Elizabeth, Chaos, Territory, Art: Deleuze and the Framing of the Earth (New York: Columbia UP, 2008).

Heidegger, Martin, "The Origin of the Work of Art," in Poetry, Language, Thought, trans. by Albert Hofstadter (New York: HarperPerenial ModernClassics, 1971),

Hewitt, Andrew, Fascist Modernism: Aesthetics, Politics, and the Avant-Garde (Stanford: Stanford University Press, 1993).

Klunchun, Pichet, "Thoughts on the Future Perfect of My Dance as Demon," Dance, ed. André Lepecki (London: The MIT Press, 2012).

Kristeva, Julia, Nations without Nationalism, trans. by Leon Roudiez (New York: Columbia University Press, 1993). Strangers to Ourselves, trans. by Leon S. Roudiez (New York: Columbia University Press, 1991).

Laclau, Ernesto and Chantal Mouffe, Hegemony and Socialist Strategy (London: Verso, 1985).

Loewald, Hans, "The Therapeutic Action of Psychoanalysis," in Papers on Psychoanalysis (New Haven: Yale University Press)

Paxton, Steve, "Fall After Newton," in Dance, ed. by André Lepecki (London: The MIT Press, 2012).

Poggioli, Renato, The Theory of the Avant-Garde, trans. by Gerald Fitzgerald (Cambridge, MA: The Belknap Press of Harvard University Press, 1981).

Sholtz, Janae, The Invention of a People: Heidegger and Deleuze on Art and the Political (Edinburgh: Edinburgh University Press, 2015).

(C) 2017 Adam Rosen-Carole

https://www.kritike.org/journal/issue 21/rosen-carole december2017.pdf

ISSN 1908-7330

(c) ) BY-NC-ND 